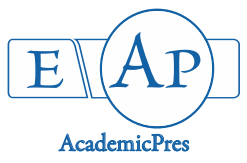

Jamali A et al. (2021)

Notulae Scientia Biologicae 13(1):10870

DOI: $10.15835 / \mathrm{nsb} 13110870$

Research Article

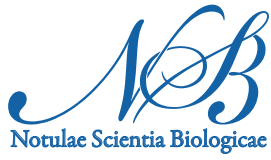

\title{
Study of drought stress effect on some growth indices and yield and yield components in 20 genotypes of bread wheat
}

\author{
Ali JAMALI, Yousef SOHRABI*, Adel SIO-SE MARDEH, \\ Farzad HOSEINPANAHI
}

\author{
University of Kurdistan, Department of Agronomy,Iran; Alijamali1344369@gmail.com; \\ y.sohrabi@uok.ac.ir(*corresponding author); adelsiosemardeh@yahoo.com; mehmesh@outlook.com
}

\begin{abstract}
An experiment was carried out with twenty genotypes in Kurdistan province in two growing season years. Grain yield was highest for the third group with $219.87 \mathrm{~g} / \mathrm{m}^{2}$. Grain yield was the lowest in the first group $\left(173.40 \mathrm{~g} / \mathrm{m}^{2}\right)$, which was not significantly different with the second group $\left(191.22 \mathrm{~g} / \mathrm{m}^{2}\right)$. But in second crop year, the highest rate of radiation use efficiency related to the first group with 2.69. In contrast, the lowest radiation use efficiency was related to second and third groups with 2.57 and 2.54, respectively. The highest grains yield was observed in the second group with $315.40 \mathrm{~g} / \mathrm{m}^{2}$. In contrast, the lowest amount of grain yield was related to the third group with $253.75 \mathrm{~g} / \mathrm{m}^{2}$. Based on the results of biplot, in the first year of cultivation, high yield genotypes included 'G14' $\left(263.00 \mathrm{~g} / \mathrm{m}^{2}\right)$, 'G20' $\left(264.50 \mathrm{~g} / \mathrm{m}^{2}\right)$, 'G18' $\left(214.00 \mathrm{~g} / \mathrm{m}^{2}\right)$ and 'G19' $\left(222.50 \mathrm{~g} / \mathrm{m}^{2}\right)$ has a higher correlation with biologic yield, grain yield, radiation use efficiency, harvest index, root Length, number of panicles, 1000-grain weight, root dry weight and number of grain per panicle traits. In the second year of cultivation, high-yield genotypes included 'G7' $\left(356.42 \mathrm{~g} / \mathrm{m}^{2}\right)$ and G9 $\left(356.75 \mathrm{~g} / \mathrm{m}^{2}\right)$ have high correlation with number of grains per square meter trait. These results indicate that under stress conditions, more traits play a role in justifying the grain yield of wheat.
\end{abstract}

Keywords: cluster analysis; correlation; principal component analysis; RUE

\section{Introduction}

Drought stress is one of the most important abiotic stress that negatively influences on plant growth and development (Rana et al., 2013). Drought stress in plants occurs when transpiration rate from leaf surfaces is higher than the water uptake by roots. Continuous decline of precipitation simultaneously with higher evapotranspiration demand, has exacerbated the drought stress. Among the crops, wheat is the most adaptable of crop to environmental conditions, especially drought stress. This plant provides about $50 \%$ protein and calories of one-third

In Iran, wheat grain filling period usually is subjected to drought stress and generally, drought stress in these regions be caused by low winter rainfall and high evaporation demand (Saeidi and Abdoli, 2015). Solar radiation is considered as an environmental source of stable and effective on crop production. There is a positive relationship between crop yield and light absorption (Zhang et al., 2019). Therefore, there are this opportunity

Received: 23 Dec 2020. Received in revised form: 27 Jan 2021. Accepted: 29 Jan 2021. Published online: 01 Feb 2021.

From Volume 13, Issue 1, 2021, Notulae Scientia Biologicae journal will use article numbers in place of the traditional method of continuous pagination through the volume. 
that the crop yield increased with increasing light use efficiency by plant (Ojeda et al., 2018). As modern agriculture is increasingly shifted to marginal lands and drought events become more frequent and intense, specific root morphological traits that can improve drought tolerance and sustain yields in suboptimal conditions hold immense potential. Moderate drought stress can significantly increase the root length density of the soil profile (Learnmore et al., 2016). Several researchers (Reynolds et al., 2005) have suggested that a deep, wide-spreading and much-branched root system is essential in the design of drought-tolerant crops. On the other hand, Lonbani and Arzani (2011) suggested that small root systems could provide benefits in waterlimited situations through improved water use efficiency.

In order to study of yield and yield components of wheat grain, it can be divided to numerical component such as grain number and weight and/or physiological components such as biomass and harvest index. In terms of numerical components, wheat grain yield has strong relationship with the increase of grain number (Sanchez-Garcia et al., 2013). In some regions, especially in recent decades, grain weight has had an important role in increase of wheat grain yield (Wu et al., 2013). Grain number is mainly determined by number of floret survival within spiklets in the preanthesis (Gonzalez-Navarro et al., 2015). The spike dry weight of wheat is expressed as a function of spike growth duration, crop growth rate and biomass partitioning to spikes, and the increasing in any one of these traits in parenthesis critical during is useful for spikes growth and production of live florets (Fischer, 2011). Farnia and Trk (2015) reported that drought stress has had the negative effect and significant on the yield and yield components of grain, such as number of ears per $\mathrm{m}^{2}, 1000$ kernel weight and biological yield. The study results of Wafa et al. (2014) showed that drought stress had significant effect on grain yield, ear per m2, grain per ear, 1000-kernel and biological yield. Mainly, the increase of grain yield in different wheat genotypes under drought stress conditions is due to increasing grain per ear, and it effect on grain yield under this condition is also greater than 1000-kernel weight. (Slafer and Araus, 1998). Fischer (2011) stated that there was strongly relationship between grain per $\mathrm{m} 2$ and TDM in wheat under drought stress condition. Results of Slafer and Araus (1998) study showed that the end of season drought reduced grain yield. Therefore, selection of genotypes with the more growth vigour in early season when there is sufficient moisture in the soil, can by absorbing of sufficient moisture quickly entered reproductive stage from the vegetative stage, and this leading to increase of harvest index and grain yield, because wheat has more time to use of moisture stored in the soil, before occurs the end of season drought.

With regards to the growing population of world and the necessity of providing food for this population, especially in developing countries and also in regard to the water deficit in arid and semi-arid regions of world and occurrence of long-term stresses in this regions, including Iran, especially in recent decades, it is important recognize and identification of genotypes in such situations that have the more grain yield and stable. Therefore, this study was conducted in order to investigate the effect of some morphological and physiological traits affecting on grain yield to identify the best genotype or genotypes in terms of grain yield and yield stability among 20 genotypes of bread wheat studied in stress conditions in Kurdistan province.

\section{Materials and Methods}

\section{Study site and experimental design}

In order to study effects of some physiological and morphological traits on wheat grain yield, an experiment was conducted at the research farms of the Faculty of Agriculture, Kurdistan University, Sanandaj, Iran ( $35^{\circ} 37^{\prime} \mathrm{N}, 4^{\circ} 22^{\prime} \mathrm{E}, 1494 \mathrm{~m}$ asl) in two growing season years (2017-2018 and 2018-2019). The experiment was carried out in a randomized complete block design with three replications and in these experiments, 20 genotypes of dry-land wheat (Table 1) were tested and compared under stress conditions (dry land). The meteorological characteristics of the study region are given in Table 2. 
Table 1. Genotypes of rain-fed wheat used in this experiment

\begin{tabular}{|c|c|c|}
\hline Genotype & Cross & Origin \\
\hline 3 & DHARWAR DRY & SIMMYT \\
\hline 12 & BERKUT/MUU//DANPHE \# 1 & SIMMYT \\
\hline 18 & $\begin{array}{l}\text { SNLG/3/EMB16/CBRD//CBRD/ } \\
\text { 4/KA/NAC//TRCH }\end{array}$ & SIMMYT \\
\hline 9 & $\begin{array}{l}\text { WORRAKATTA/2*PASTOR//D } \\
\text { ANPHE \# } 1\end{array}$ & SIMMYT \\
\hline 15 & $\begin{array}{l}\text { C80.1/3*BATAVIA//2*WBLL1/3/ } \\
\text { EMB16/CBRD//CBRD/4/CHEW } \\
\text { INK \# } 1\end{array}$ & SIMMYT \\
\hline 17 & $\begin{array}{l}\text { SNLG/3/EMB16/CBRD//CBRD/ } \\
\text { 4/KA/NAC//TRCH }\end{array}$ & SIMMYT \\
\hline 11 & $\begin{array}{l}\text { QING } \\
\text { HAIBEI/WBLL1//BRBT2/3/PAU } \\
\text { RAQ }\end{array}$ & SIMMYT \\
\hline 25 & $\begin{array}{l}\mathrm{KA} / \mathrm{NAC} / / \mathrm{TRCH} / 4 / \mathrm{MILAN} / \mathrm{KA} \\
\mathrm{UZ} / / \mathrm{DHARWAR} \text { DRY/3/BAV92 }\end{array}$ & SIMMYT \\
\hline 30 & $\begin{array}{l}\text { BAV92//IRENA/KAUZ/3/HUIT } \\
\text { ES/4/2*ROLF07 }\end{array}$ & SIMMYT \\
\hline 36 & $\begin{array}{l}\text { WBLL1/4/BOW/NKT//CBRD/3 } \\
\text { /CBRD/5/WBLL1*2/TUKURU }\end{array}$ & SIMMYT \\
\hline 45 & $\begin{array}{l}\text { FRANCOLIN } \\
\# 1 / / \text { WBLL1*2/KURUKU }\end{array}$ & SIMMYT \\
\hline 48 & BAJ \# 1/TECUE \# 1 & SIMMYT \\
\hline 2 & HIDDAB & SIMMYT \\
\hline 'Azar-2' & - & Iran \\
\hline 'Karim' & - & Iran \\
\hline 'Cross sabalan' & - & Iran \\
\hline 'Rizhab' & - & Iran \\
\hline 'Avihang' & - & Iran \\
\hline 'Todar' & - & Iran \\
\hline 'Siosemardeh' & - & Iran \\
\hline
\end{tabular}

Table 2. Means of monthly rainfall and temperature in 2017-2018 and 2018-2019 at Kurdistan province during the growing seasons

\begin{tabular}{|c|c|c|c|c|c|c|c|c|c|c|}
\hline Region & $\begin{array}{c}\text { Climate } \\
\text { parameters }\end{array}$ & NOV & DEC & JAN & FEB & MAR & APR & MAY & JUN & JUL \\
\hline \multirow{2}{*}{$2017-$} & Rainfall (mm) & 24.9 & 12 & 25 & 15.5 & 43.3 & 15.8 & 9.5 & 1 & 0 \\
\cline { 2 - 11 } 2018 & $\begin{array}{c}\text { Mean temp } \\
\left(\mathrm{C}^{\circ}\right)\end{array}$ & 0 & 5.5 & 1.3 & 1.9 & 8.7 & 13.9 & 18.9 & 25.5 & 28.8 \\
\hline \multirow{2}{*}{$2018-$} & Rainfall (mm) \\
\cline { 2 - 12 } 2019 & $\begin{array}{c}\text { Mean temp } \\
\left(\mathrm{C}^{\circ}\right)\end{array}$ & 64.7 & -3.4 & 1.9 & 3.4 & 7.4 & 10.5 & 16.6 & 21.5 & 26.3 \\
\hline
\end{tabular}

\section{Field preparation and plots establishment}

Each experimental plot consists of six row, $6 \mathrm{~m}$ in length and with $20 \mathrm{~cm}$ apart. Seeds were sown with a density 400 seed m m $^{-2}$ in 20 November 2017-2018 and 2018-2019. Fertilizer recommendations were conducted based on the results of soil analysis of experimental farms in Kurdistan. The amount of fertilizer used before sowing in both locations was considered about $50 \mathrm{~kg} \mathrm{~N}$ (urea) and $50 \mathrm{~kg} \mathrm{P} \mathrm{(Ammonium} \mathrm{phosphate)} \mathrm{ha}{ }^{-1}$. 


\section{Measuring of light absorption percentage and radiation use efficiency}

In order to determine the percentage of light received by wheat, the light of above and under canopy was measured by tube photometer (model LICOR-LI-250A) in 5 stages in each treatment based on different growth stages of wheat and light absorption percentage determine by function 1 (Gardner et al., 1985).

$$
\% I_{a b s}=\left(\frac{I_{0}-I}{I_{0}}\right) \times 100
$$

In this function: \%Iabs=light absorption percentage, $\mathrm{I} 0=$ light above canopy, $\mathrm{I}=$ light under canopy. Radiation use efficiency $(\mathrm{g} / \mathrm{Mj})$ obtained via slope of linear regression between total biomass $(\mathrm{g} / \mathrm{m} 2)$ and the total photosynthetically active radiation absorbed by the plants canopy during the growing season (Bange at al., 1997).

\section{Data collection}

Leaf relative water content (RWC)

Leaf relative water content were measured at solar noon on 10 flag leaves in two growth stages (late booting, early grain filing). In this way, ten leaves were cut from each plot at $8.00 \mathrm{a} . \mathrm{m}$., weighed immediately (fresh weight, $\mathrm{FW}$ ), floated in the dark for $24 \mathrm{~h}$ to achieve turgidity (turgid weight, TW), then oven-dried (105 $\left.{ }^{\circ} \mathrm{C}\right)$ for $24 \mathrm{~h}$ and weighed again (dry weight, DW). The WSD of leaves was calculated as follows: WSD $=[(\mathrm{TW}$ $-\mathrm{FW}) /(\mathrm{TW}-\mathrm{DW})] \times 100 \%$. Relative water content $(\mathrm{RWC})$ was calculated as follows: RWC $(\%)=($ fresh FW-DW)/(TW $-\mathrm{DW}) \times 100$.

\section{Agronomic traits}

At the end of growing season, the final harvest was performed by harvesting four middle rows at physiological maturity and the plants of $1 \mathrm{~m}^{2}$ was harvested from each plot. The roots and shoots were separated and washed with deionized distilled water. Root traits such as root length and root dry weight were measured. Then the yield components such as ear per $\mathrm{m}^{2}$, grain per ear by counting grains per ear. Then grains were separated from the rest of plant parts, grain yield and 1000-kernel weight were determined by weighting the 1000 grains harvested in one $\mathrm{m}^{2}$ from each plot. In the following, in order to determine of biological yield, after drying of wheat shoots, the harvested plants of each plot $\left(1 \mathrm{~m}^{2}\right)$ were weighed by digital scale and then dried plants with grain yield were considered as biological yield. Harvest index was calculated according to the following formula: Harvest index $(\%)=($ Grain yield $/$ Biological yield $) \times 100$.

\section{Statistical analysis}

All data were subjected to two-way analysis of variance (ANOVA) and expressed as the means. Differences among treatments were analyzed by Least significant difference (LSD) test at $\mathrm{P} \leq 0.05$. General correlations between parameters were examined with Pearson's correlation coefficients. Correlations were considered statistically significant and are indicated at ns, not significant; ${ }^{*}$ at $\mathrm{P} \leq 0.05$ and ${ }^{* *}$ at $\mathrm{P} \leq 0.01$. Principal component analysis (PCA) was performed to visualize the similarities or differences in all traits under different drought stress using SAS and the results of this analysis are presented as bi-plots.

The data were explored through analysis of variance, as well as comparisons of means using the least significant difference (LSD) test. All statistical analyses were performed using SPSS 13.0 and differences were deemed significant if $\mathrm{P}<0.05$.

Clustering was performed in S-PLUS ver. 6.1 software (Insightful Corporation, USA) using Ward's hierarchical approach based on minimum variance linking method with Euclidean distance as the similarity measure. Prior to cluster analysis, the seminal root data were standardized by subtracting the values for each genotype from the overall mean and then dividing by the standard deviation. 


\section{Results}

The results of Bartlett's test were shown in Table 3. Bartlett's test result showed that for most of studied traits there was a significant difference between two crop years, and therefore other statistical analysis was done separately from each crop year. Based on the results, there was a good variation among genotypes based on the different traits studied in the first and second years (Table 4). The cluster analysis of different wheat genotypes based on the UPGMA method in the first and second years was shown in Figure 1. Dendrogram obtained from cluster analysis in the first year showed that 20 wheat genotypes were separated into three groups. So, in the first, second and third clusters, five genotypes, 11 genotypes and four genotypes were placed respectively. On the other hand, cluster analysis in the second year segregated the genotypes into three groups. So that in the first, second and third groups were 8,11 and 1 genotypes, respectively.

Table 3. Bartlett's test related to different studied traits among wheat genotypes for two crop year

\begin{tabular}{|c|c|c|c|c|c|c|}
\hline Trait & Year & EDF & ESS & EMS & CHISQ & Significant \\
\hline \multirow{2}{*}{ Root Length } & First & 57 & 9838.45 & 517.81 & \multirow{2}{*}{22.66} & \multirow{2}{*}{$* *$} \\
\hline & Second & 57 & 2656.51 & 46.61 & & \\
\hline \multirow{2}{*}{ Root dry weight } & First & 57 & 23.02 & 1.21 & \multirow{2}{*}{60.65} & \multirow{2}{*}{$* *$} \\
\hline & Second & 57 & 2.40 & 0.04 & & \\
\hline \multirow{2}{*}{$\begin{array}{c}\text { Relative water } \\
\text { content }\end{array}$} & First & 57 & 593.63 & 31.24 & \multirow{2}{*}{0.63} & \multirow{2}{*}{$\mathrm{ns}$} \\
\hline & Second & 57 & 480.34 & 8.43 & & \\
\hline \multirow{2}{*}{ Biologic yield } & First & 57 & 337353.45 & 17755.44 & \multirow{2}{*}{20.24} & \multirow{2}{*}{$* *$} \\
\hline & Second & 57 & 98301.25 & 1724.58 & & \\
\hline \multirow{2}{*}{ Harvest index } & First & 57 & 0.17 & 0.01 & \multirow{2}{*}{27.09} & \multirow{2}{*}{$* *$} \\
\hline & Second & 57 & 0.04 & 0.00 & & \\
\hline \multirow{2}{*}{ Spikelet per panicle } & First & 57 & 304.22 & 16.01 & \multirow{2}{*}{162.91} & \multirow{2}{*}{$* *$} \\
\hline & Second & 57 & 4.38 & 0.08 & & \\
\hline \multirow{2}{*}{ Number of panicles } & First & 57 & 656816.74 & 34569.30 & \multirow{2}{*}{27.85} & \multirow{2}{*}{$* *$} \\
\hline & Second & 57 & 152160.01 & 2669.47 & & \\
\hline \multirow{2}{*}{1000 -grain weight } & First & 57 & 1353.98 & 71.26 & \multirow{2}{*}{4.56} & \multirow{2}{*}{ * } \\
\hline & Second & 57 & 764.08 & 13.40 & & \\
\hline \multirow{2}{*}{$\begin{array}{c}\text { Number of grains per } \\
\text { spikelet }\end{array}$} & First & 57 & 2.46 & 0.13 & \multirow{2}{*}{0.21} & \multirow{2}{*}{ ns } \\
\hline & Second & 57 & 2.84 & 0.05 & & \\
\hline \multirow{2}{*}{$\begin{array}{l}\text { Number of grains per } \\
\text { panicle }\end{array}$} & First & 57 & 844.61 & 44.45 & \multirow{2}{*}{2.2} & \multirow{2}{*}{ ns } \\
\hline & Second & 57 & 568.49 & 9.97 & & \\
\hline \multirow{2}{*}{$\begin{array}{c}\text { Number of grains per } \\
\text { square meter }\end{array}$} & First & 57 & 69623469.08 & 3664393.11 & \multirow{2}{*}{3.24} & ns \\
\hline & Second & 57 & 112704332.24 & 1977268.99 & & 110 \\
\hline Radiation use & First & 57 & 10.76 & 0.57 & 0.07 & ns \\
\hline efficiency & Second & 57 & 9.99 & 0.18 & 0.07 & 115 \\
\hline Grain vield & First & 57 & 99077.50 & 5214.61 & 23.8 & ** \\
\hline Giam yicta & Second & 57 & 25831.79 & 453.19 & 25.0 & \\
\hline
\end{tabular}

[EDF (degree of freedom for error), ESS (sum of square for error), EMS (mean square for error), CHISQ (chi square),

* (significant at $5 \%$ probability level), ${ }^{* *}$ (significant at $1 \%$ probability level) and NS (not significant)] 
Jamali A et al. (2020). Not Sci Biol 13(1):10870

Table 4. Descriptive statistics related to different studied traits in wheat genotypes under two crop year

\begin{tabular}{|c|c|c|c|c|c|c|c|c|c|c|}
\hline \multirow[b]{2}{*}{ Traits } & \multicolumn{5}{|c|}{ First year } & \multicolumn{5}{|c|}{ Second year } \\
\hline & Minimum & Maximum & Mean & $\begin{array}{c}\text { Std. } \\
\text { deviation }\end{array}$ & $\mathrm{CV}(\%)$ & Minimum & Maximum & Mean & $\begin{array}{c}\text { Std. } \\
\text { deviation }\end{array}$ & $\mathrm{CV}(\%)$ \\
\hline Root length & 60.50 & 105.00 & 90.72 & 11.37 & 12.54 & 57.75 & 100.25 & 86.69 & 10.68 & 12.32 \\
\hline $\begin{array}{c}\text { Root dry } \\
\text { weight }\end{array}$ & 1.45 & 3.45 & 2.35 & 0.55 & 23.39 & 1.28 & 3.24 & 2.19 & 0.54 & 24.85 \\
\hline $\begin{array}{c}\text { Relative } \\
\text { water } \\
\text { content }\end{array}$ & 73.37 & 83.33 & 77.90 & 2.79 & 3.58 & 78.75 & 87.96 & 85.05 & 2.41 & 2.84 \\
\hline $\begin{array}{c}\text { Biologic } \\
\text { yield }\end{array}$ & 548.25 & 815.50 & 688.77 & 66.62 & 9.67 & 770.00 & 1120.00 & 1003.88 & 88.91 & 8.86 \\
\hline $\begin{array}{c}\text { Harvest } \\
\text { index }\end{array}$ & 0.20 & 0.40 & 0.28 & 0.04 & 16.78 & 0.28 & 0.33 & 0.30 & 0.01 & 4.68 \\
\hline $\begin{array}{l}\text { Spikelet per } \\
\text { panicle }\end{array}$ & 9.05 & 16.97 & 13.46 & 2.00 & 14.86 & 9.50 & 16.93 & 13.68 & 2.10 & 15.36 \\
\hline $\begin{array}{c}\text { Number of } \\
\text { panicles }\end{array}$ & 347.00 & 679.75 & 457.88 & 92.96 & 20.30 & 389.00 & 765.25 & 507.24 & 107.58 & 21.21 \\
\hline $\begin{array}{c}\text { 1000-grain } \\
\text { weight }\end{array}$ & 21.02 & 34.02 & 25.97 & 4.22 & 16.25 & 22.98 & 36.23 & 28.98 & 3.96 & 13.65 \\
\hline $\begin{array}{l}\text { Number of } \\
\text { grains per } \\
\text { spikelet }\end{array}$ & 1.00 & 1.63 & 1.25 & 0.18 & 14.40 & 1.24 & 2.07 & 1.59 & 0.22 & 14.01 \\
\hline $\begin{array}{l}\text { Number of } \\
\text { grains per } \\
\text { panicle }\end{array}$ & 9.86 & 22.99 & 16.82 & 3.33 & 19.81 & 11.80 & 25.87 & 21.98 & 4.85 & 22.08 \\
\hline $\begin{array}{l}\text { Number of } \\
\text { grains per } \\
\text { square meter }\end{array}$ & 5727.54 & 9571.80 & 7441.76 & 957.13 & 12.86 & 7930.40 & 12933.31 & 10653.44 & 1374.45 & 12.90 \\
\hline $\begin{array}{c}\text { Radiation } \\
\text { use efficiency }\end{array}$ & 2.04 & 3.59 & 2.64 & 0.37 & 14.21 & 2.08 & 3.08 & 2.62 & 0.25 & 9.47 \\
\hline Grain yield & 127.25 & 264.50 & 192.50 & 36.10 & 18.75 & 243.18 & 356.75 & 302.29 & 34.83 & 11.52 \\
\hline
\end{tabular}
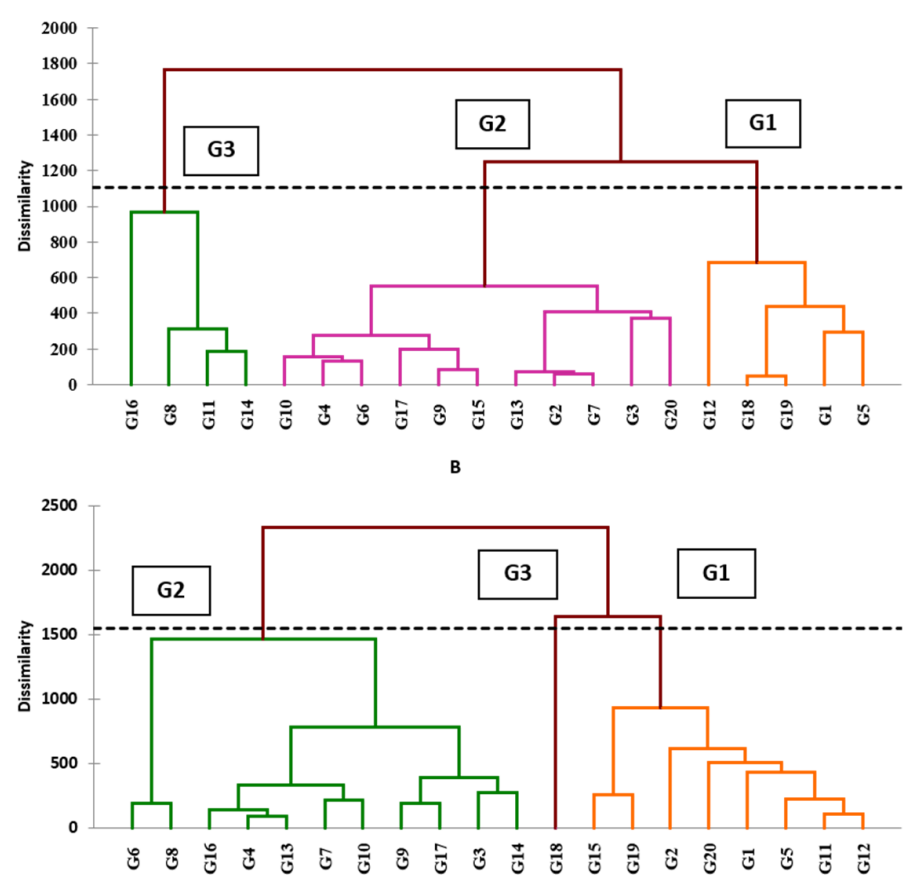

Figure 1. Dendrograms derived from cluster analysis related to different crop year in wheat genotypes [A (first year) and B (second year)] 


\section{Comparison of the mean for cluster groups in the first year}

The mean comparison between the cluster analysis groups was shown in Table 5. The highest root length in the first group was observed with $94.1 \mathrm{~cm}$. But the second and third groups did not differ significantly in root length trait. The highest and lowest root dry weight was in the third and first group, respectively. The highest relative water content in the first group (79.09\%) was observed, which was not statistically significant in the second group (78.03\%). In contrast, the lowest relative water content was for the third cluster $(76.07 \%)$. The highest biological yield of the third group was $728.6 \mathrm{~g} / \mathrm{m}^{2}$. In contrast, the lowest amount was $656.1 \mathrm{~g} / \mathrm{m}^{2}$. The highest and lowest harvest index was observed in groups 3 and 1, respectively. Spikelet per panicle had the highest rate of 13.93 in the third group. Spikelet per panicle was the lowest in the first group (13.04). In addition, the highest and lowest number of panicles was observed in the third and first groups with 13.93 and 13.04, respectively. The results of the mean comparison showed that the highest number of panicles was in the first group with 487.45 per square meter. In contrast, the lowest number of panicles was in the second group, which did not have a significant difference with the third group. The highest 1000-grain weight was observed in the first group with $27.66 \mathrm{~g}$. In contrast, the lowest level of 1000-grain weight was in the third group, which was not statistically significant different in the second group. On the other hand, the highest number of grains per spikelet was observed in the third group with 1.43. The lowest number of grains per spikelet was observed in the first group with 1.04. Also, the highest number of grains per panicle was observed in the third group with 19.88. The lowest number of grains per panicle was observed in the first group with 13.58. The highest and lowest number of grains per square meter was for the third (8849.41) and first (6242.35) group, respectively. The highest rate radiation use efficiency was in the second and third groups, with no significant differences in their rates. In contrast, the lowest level of radiation use efficiency was for the first group. Grain yield was highest for the third group with $219.87 \mathrm{~g} / \mathrm{m} 2$. Grain yield was the lowest in the first group $\left(173.4 \mathrm{~g} / \mathrm{m}^{2}\right)$, which was not significantly different with the second group $\left(191.22 \mathrm{~g} / \mathrm{m}^{2}\right)$.

\section{Comparison of the mean for cluster groups in the second year}

Based on the results of the mean comparison between different groups, the highest root length was observed in the third group with $93.0 \mathrm{~cm}$ (Table 5). In contrast, the lowest root length was observed in the second group with $85.3 \mathrm{~cm}$. In addition, the highest and lowest root dry weight was observed in the third (2.76 $\mathrm{g})$ and the first $(1.99 \mathrm{~g})$ group, respectively. The results of the mean comparison indicated that the highest relative water content in the second group (85.3\%) was observed, which is not statistically significant different with the first group (85.15\%). The lowest level of relative water content was observed in the third group $(81.35 \%)$. The highest biologic yield related to the second group with $1038.41 \mathrm{~g} / \mathrm{m}^{2}$. In contrast, the third group had the lowest biological yield with $940.0 \mathrm{~g} / \mathrm{m}^{2}$, which had no significant difference with the first group $\left(964.38 \mathrm{~g} / \mathrm{m}^{2}\right)$.

The results of the mean comparison of the harvest index showed that there was no significant difference between the first and the second groups and the highest harvest index $(30 \%)$ was obtained by these groups. In contrast, the lowest harvest index (28\%) was for the third group. The highest spikelet per panicle was in the first and second groups (14.37), with no significant difference. Spikelet per panicle was the lowest for the third group with 9.5. On the other hand, the number of panicles attributed to the third group was 668.25. In contrast, the lowest number of panicles related to the first (502.59) and the second (495.98) groups. The results of the mean comparison of 1000-grain weight showed that the highest amount was related to the third group with $32.96 \mathrm{~g}$. In contrast to the lowest 1000-grain weight belonged to the second group with $27.26 \mathrm{~g}$. The results of the mean comparison for number of grains per spikelet showed that there is a significant difference between the cluster groups. So that the highest level was in the second group with 1.67. But against the lowest level, the third group was 1.24 . 
Table 5. Mean comparison between different groups of cluster analysis based on different studied traits at two crop years

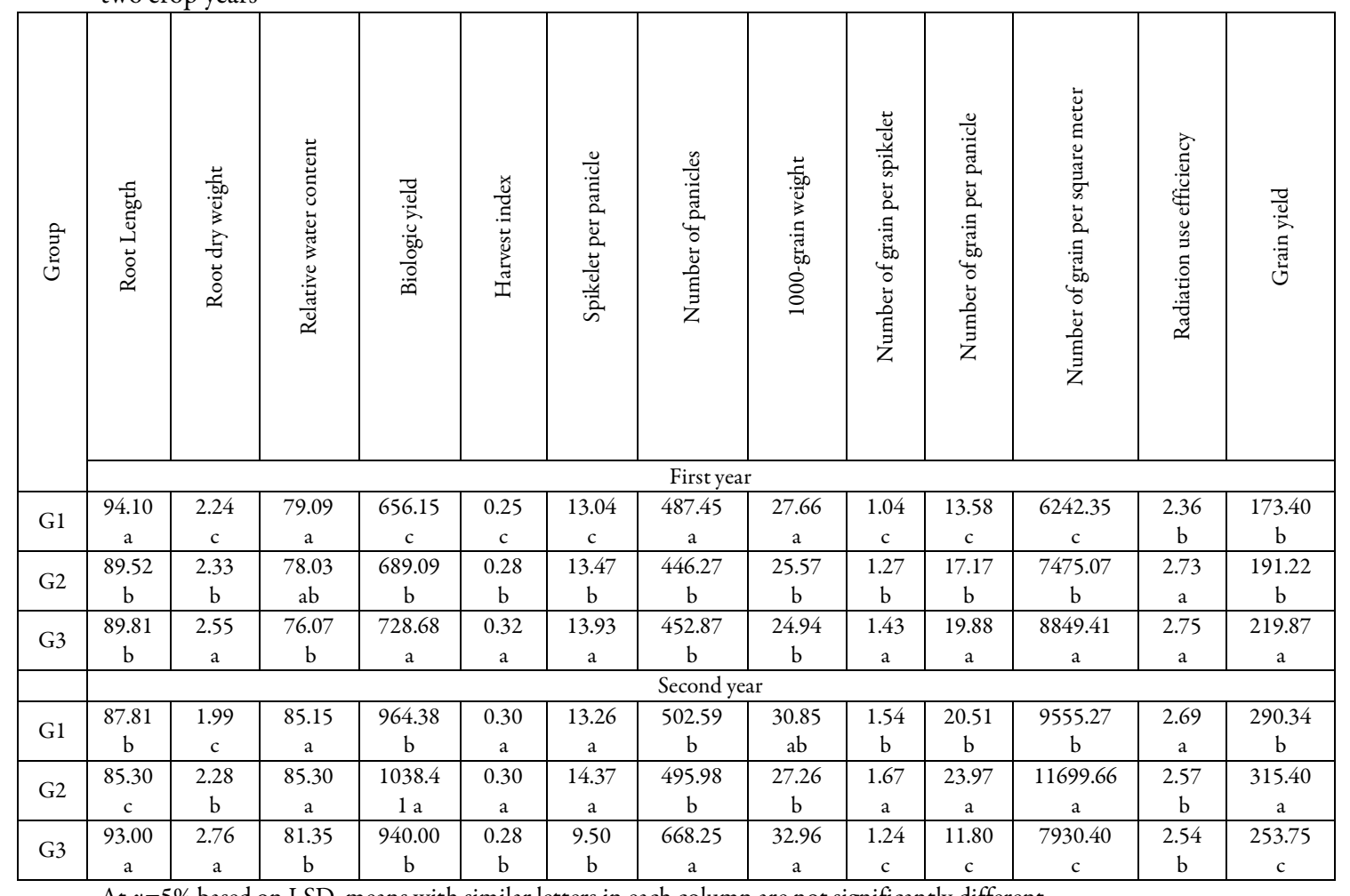

The highest number of grains per panicle was observed in the second group with 23.97. The lowest number of grains per panicle was for the third group at 11.80. In addition, the highest number of grains per square meter was in the second group (11699.66). The lowest number of grains per square meter for the third group was 7930.40. The highest rate of radiation use efficiency related to the first group with 2.69. In contrast, the lowest radiation use efficiency was related to second and third groups with 2.57 and 2.54, respectively. The highest grains yield was observed in the second group with $315.40 \mathrm{~g} / \mathrm{m}^{2}$. In contrast, the lowest amount of grain yield was related to the third group with $253.75 \mathrm{~g} / \mathrm{m}^{2}$.

\section{Principal component analysis}

The results of the principal component analysis based on all the traits studied were shown in Table 6 . The results of principal component analysis in the first year showed that the three components with eigenvalue were higher than one, so that the first, second and third components had an Eigenvalue of 5.65, 3.14 and 1.22, respectively. The results of the principal component analysis showed that the first three components accounted for $77.13 \%$ of the total variance. In addition, the first, second and third components have a relative variance of 43.5, 24.20 and $9.42 \%$, respectively. In the first component, the traits root dry weight, relative water content, biologic yield, harvest index, spikelet per panicle, number of panicles, 1000-grain weight, radiation use efficiency and grain yield have the highest load factor. In addition, in the second component, the number of grains per spikelet, number of grains per panicle, and number of grains per square meter traits yielded the highest factor load. The root Length trait in the third component accounted for the highest factor load. However, the results of principal component analysis based on all the traits studied in the second year were somewhat different. So that the first three components had an eigenvalue greater than one with 5.35, 2.38 and 1.7 , respectively. The three components totaled $72.60 \%$ of the total variance. The results showed that the first component had the highest variance (41.15\%). After that, the second and third components had the highest 
variance of $18.34 \%$ and $13.10 \%$, respectively. In the first component, the traits root dry weight, relative water content, spikelet per panicle, number of panicles, 1000-grain weight, number of grains per spikelet, number of grains per panicle and number of grains per square meter have the highest load factor. In the second component, the biologic yield and grain yield traits had the highest load factor. Also, root dry weight, harvest index and 1000-grain weight traits in the third component have the highest load factor.

Table 6. The Results of principal component analysis based on different studied traits at two crop year

\begin{tabular}{|c|c|c|c|c|c|c|}
\hline \multirow{2}{*}{ Traits } & \multicolumn{3}{|c|}{ First year } & \multicolumn{3}{c|}{ Second year } \\
\cline { 2 - 7 } & PC1 & PC2 & PC3 & PC1 & PC2 & PC3 \\
\hline Root length & 0.271 & -0.161 & 0.737 & -0.270 & -0.431 & -0.190 \\
\hline Root dry weight & 0.710 & -0.078 & 0.312 & -0.636 & 0.169 & -0.615 \\
\hline Relative water content & -0.771 & -0.103 & -0.233 & 0.876 & -0.131 & 0.097 \\
\hline Biologic yield & 0.723 & 0.211 & 0.182 & -0.211 & 0.889 & -0.163 \\
\hline Harvest index & 0.704 & 0.462 & -0.144 & 0.335 & -0.097 & 0.544 \\
\hline Spikelet per panicle & -0.760 & 0.358 & 0.445 & 0.829 & 0.100 & 0.124 \\
\hline Number of panicles & 0.826 & -0.437 & -0.022 & -0.906 & 0.072 & -0.203 \\
\hline 1000-grain weight & 0.817 & -0.334 & -0.267 & -0.630 & 0.178 & 0.684 \\
\hline Number of grains per spikelet & 0.112 & 0.859 & -0.352 & 0.783 & 0.143 & -0.224 \\
\hline Number of grains per panicle & -0.446 & 0.876 & 0.073 & 0.972 & 0.157 & -0.082 \\
\hline Number of grains per square meter & 0.341 & 0.858 & 0.134 & 0.585 & 0.543 & -0.455 \\
\hline Radiation use efficiency & 0.603 & 0.304 & 0.188 & -0.376 & 0.490 & 0.230 \\
\hline Grain yield & 0.921 & 0.288 & -0.156 & 0.026 & 0.852 & 0.342 \\
\hline Eigenvalue & 5.656 & 3.147 & 1.225 & 5.350 & 2.384 & 1.704 \\
\hline Relative variance (\%) & 43.507 & 24.208 & 9.420 & 41.155 & 18.340 & 13.108 \\
\hline Cumulative variance \% & 43.507 & 67.716 & 77.136 & 41.155 & 59.495 & 72.604 \\
\hline
\end{tabular}

The biplot charts based on the first and second components of the first and second year were shown in Figure 2. Based on the biplot chart in the first year, genotypes 'G14', 'G16', 'G17', 'G13', 'G15', 'G7' and 'G8' were classified into one group. Also, biplot chart based on all studied traits showed that grain yield, biologic yield, radiation use efficiency, harvest index, number of grains per square meter and number of grains per spikelet traits were classified into one group and had a strong association with genotypes 'G14', 'G16', 'G17', 'G13', 'G15', 'G7' and 'G8'. In addition, the results of biplot chart showed that genotypes 'G11', 'G9', 'G3', 'G2' and 'G4' were in one group and had a stronger relationship with number of grains per panicle and spikelet per panicle traits. On the other hand, based on the biplot, the genotypes 'G10', 'G6', 'G12', 'G5' and 'G1' were also adjacent to each other and were associated with the relative water content trait. In addition, 'G20', 'G18' and 'G19' genotypes were grouped in one group based on the first and second components and had a stronger association with root Length, root dry weight, number of panicles and 1000-grain weight traits. But the results of biplot were somewhat different in the second year. So that genotypes 'G8', 'G9', 'G7', 'G10' and 'G12' in the neighborhood, and those with grain yield, number of grains per square meter, number of grains per spikelet, spikelet per panicle and number of grains per panicle traits had a stronger correlation. On the other hand, according to the results of biplot, 'G11', 'G17' and 'G14' genotypes were grouped in one group and showed a stronger relationship with biologic yield, radiation use efficiency, 1000-grain weight and number of panicles traits. Biplot chart showed that root dry weight, relative water content and harvest index traits were grouped in one group and had a stronger relationship with genotypes 'G1', 'G2', 'G3', 'G4', 'G5', 'G6', 'G13' and 'G16'. 

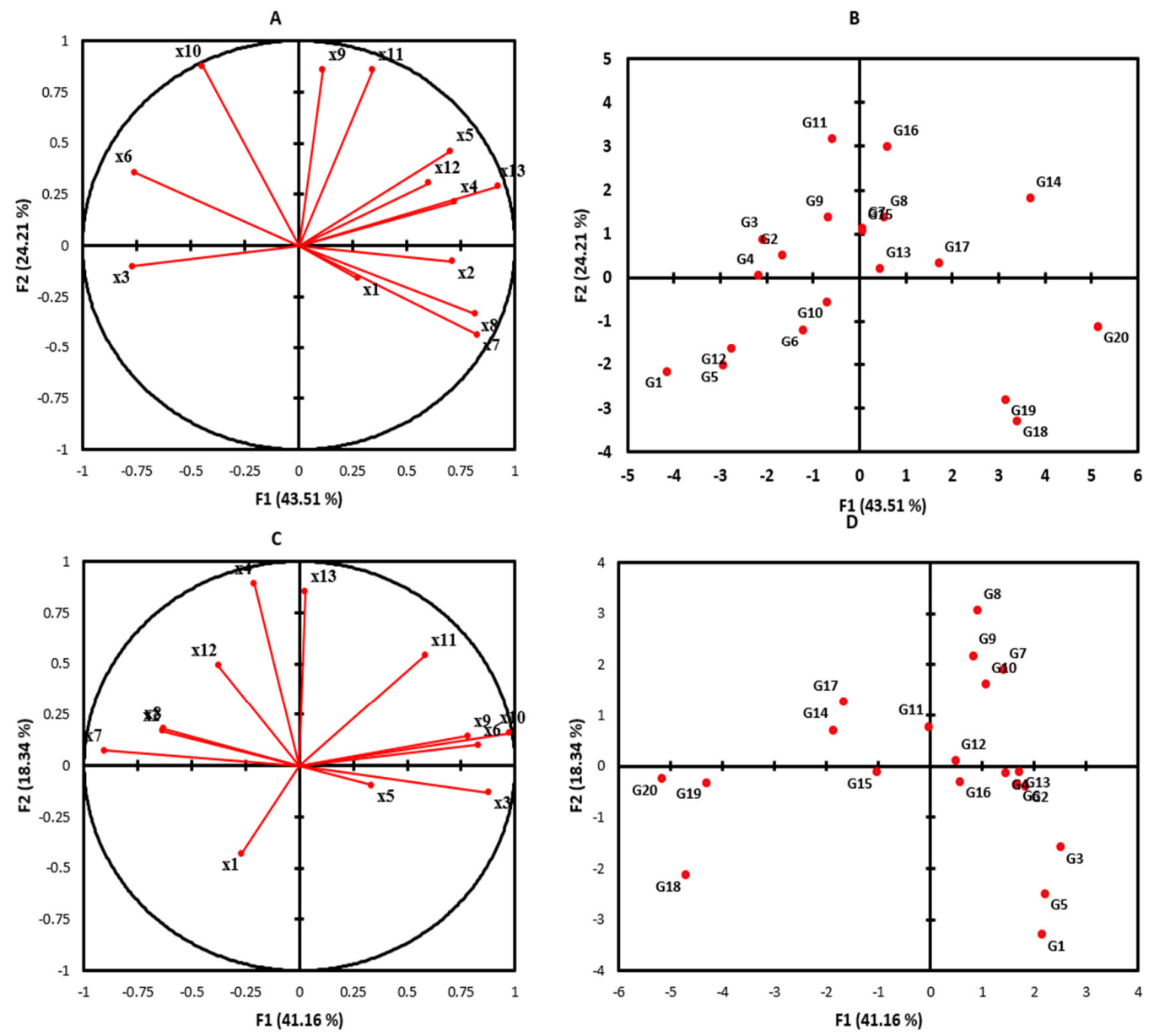

Figure 2. Biplot of the first and second components at different crop year related to different wheat genotypes [A and B (first year), $\mathrm{C}$ and D (second year)]

\section{Correlation analysis}

The results of the correlation analysis were shown in Table 7. Based on correlation analysis between all studied traits in the first year, there was a positive and significant correlation between grain yield and root dry weight, biologic yield, harvest index, number of panicles, 1000-grain weight, number of grains per square meter and radiation use efficiency traits. In contrast, relative water content and spikelet per panicle traits showed a negative and significant correlation with grain yield. In addition, biologic yield and harvest index traits showed a positive and significant correlation with radiation use efficiency traits. Also, the harvest index showed a positive and significant correlation with 1000-grain weight, number of grains per spikelet, number of grains per square meter, radiation use efficiency and grain yield traits. On the other hand, there was a positive correlation between root dry weight and traits of biologic yield, number of panicles, 1000-grain weight and grain yield. In contrast, negative correlation was found between the root dry weight and relative water content traits. There was a significant negative correlation between relative water content with root dry weight, biologic yield, harvest index, number of panicles, 1000-grain weight and grain yield traits.

The results of the correlation analysis between different traits were different in the second year with the first year. There was a positive and significant correlation between grain yield and biologic yield trait. Also, there was a significant positive correlation between root dry weight and number of panicles trait. The correlation between root dry weight and relative water content, harvest index, spikelet per panicle and number 
of grains per panicle was negative and significant. In addition, the relative water content trait showed a negative and significant correlation with relative water content and number of panicles traits. In case of correlation, the relative water content trait was positive and significant with spikelet per panicle, number of grains per spikelet and number of grains per panicle traits. Correlation analysis showed that there was a positive and significant correlation between number of grains per panicle and traits number of grains per square meter, relative water content, spikelet per panicle and number of grains per spikelet; but the relationship between the number of grains per panicle and the traits root dry weight, number of panicles and 1000-grain weight is negative and significant.

Table 7. Correlation analysis between different studied traits at two crop year

\begin{tabular}{|c|c|c|c|c|c|c|c|c|c|c|c|c|c|}
\hline \multirow{2}{*}{ Traits } & $\mathrm{x} 1$ & $\mathrm{x} 2$ & $\mathrm{x} 3$ & $\mathrm{x} 4$ & $\mathrm{x} 5$ & $\mathrm{x} 6$ & $\mathrm{x} 7$ & $\mathrm{x} 8$ & $\mathrm{x} 9$ & $\mathrm{x} 10$ & $\mathrm{x} 11$ & $\mathrm{x} 12$ & $\mathrm{x} 13$ \\
\hline & \multicolumn{13}{|c|}{ First year } \\
\hline Root Length & 1.00 & & & & & & & & & & & & \\
\hline Root dry weight & 0.30 & 1.00 & & & & & & & & & & & \\
\hline Relative water content & -0.23 & -0.66 & 1.00 & & & & & & & & & & \\
\hline Biologic yield & 0.21 & 0.46 & -0.45 & 1.00 & & & & & & & & & \\
\hline Harvest index & 0.13 & 0.33 & -0.61 & 0.36 & 1.00 & & & & & & & & \\
\hline Spikelet per panicle & -0.03 & -0.41 & 0.42 & -0.39 & -0.39 & 1.00 & & & & & & & \\
\hline Number of panicles & 0.26 & 0.59 & -0.61 & 0.46 & 0.37 & -0.83 & 1.00 & & & & & & \\
\hline 1000-grain weight & 0.17 & 0.51 & -0.45 & 0.50 & 0.49 & -0.82 & 0.72 & 1.00 & & & & & \\
\hline Number of grains per spikelet & -0.24 & -0.04 & -0.03 & 0.20 & 0.47 & -0.02 & -0.29 & -0.08 & 1.00 & & & & \\
\hline Number of grains per panicle & -0.18 & -0.31 & 0.24 & -0.13 & 0.07 & 0.69 & -0.78 & -0.63 & 0.71 & 1.00 & & & \\
\hline Number of grains per square meter & 0.03 & 0.22 & -0.43 & 0.39 & 0.62 & 0.08 & 0.03 & -0.15 & 0.70 & 0.58 & 1.00 & & \\
\hline Radiation use efficiency & 0.09 & 0.32 & -0.42 & 0.75 & 0.45 & -0.21 & 0.31 & 0.35 & 0.17 & -0.03 & 0.39 & 1.00 & \\
\hline \multirow[t]{2}{*}{ Grain yield } & 0.15 & 0.58 & -0.65 & 0.68 & 0.84 & -0.65 & 0.62 & 0.75 & 0.42 & -0.15 & 0.53 & 0.55 & 1.00 \\
\hline & \multicolumn{13}{|c|}{ Second year } \\
\hline Root Length & 1.00 & & & & & & & & & & & & \\
\hline Root dry weight & 0.35 & 1.00 & & & & & & & & & & & \\
\hline Relative water content & -0.06 & -0.65 & 1.00 & & & & & & & & & & \\
\hline Biologic yield & -0.17 & 0.35 & -0.26 & 1.00 & & & & & & & & & \\
\hline Harvest index & 0.09 & -0.45 & 0.21 & -0.28 & 1.00 & & & & & & & & \\
\hline Spikelet per panicle & -0.21 & -0.47 & 0.69 & -0.10 & 0.35 & 1.00 & & & & & & & \\
\hline Number of panicles & 0.26 & 0.68 & -0.86 & 0.27 & -0.23 & -0.81 & 1.00 & & & & & & \\
\hline 1000-grain weight & 0.07 & 0.06 & -0.44 & 0.23 & 0.05 & -0.42 & 0.39 & 1.00 & & & & & \\
\hline Number of grains per spikelet & -0.26 & -0.39 & 0.67 & -0.01 & 0.08 & 0.37 & -0.69 & -0.58 & 1.00 & & & & \\
\hline Number of grains per panicle & -0.28 & -0.50 & 0.82 & -0.05 & 0.24 & 0.83 & -0.89 & -0.61 & 0.82 & 1.00 & & & \\
\hline Number of grains per square meter & -0.23 & 0.01 & 0.34 & 0.39 & 0.14 & 0.52 & -0.28 & -0.65 & 0.55 & 0.66 & 1.00 & & \\
\hline Radiation use efficiency & -0.29 & 0.15 & -0.31 & 0.36 & -0.27 & -0.27 & 0.21 & 0.40 & -0.18 & -0.30 & -0.16 & 1.00 & \\
\hline Grain yield & -0.20 & -0.01 & -0.04 & 0.72 & 0.27 & 0.17 & 0.02 & 0.42 & 0.04 & 0.14 & 0.40 & 0.28 & 1.00 \\
\hline
\end{tabular}

Values in bold are different from 0 with a significance level alpha $=0.05$

\section{Discussion}

Based on the meteorological results shown in Table 2, it is observed that rainfall is lower in the first year but has a higher temperature. In contrast, in the second crop year, the temperature was lower but more rainfall was observed. The reason for higher yields in the second year of cultivation can be due to more water availability during the plant growth period. Also, higher temperatures can lead to more evapotranspiration and somehow the plant is exposed to tension. Many researchers have shown that drought stresses cussed the losses of yield (Wang et al., 2017; Abdel-Motagally and El-Zohri, 2018). 
As the moisture content of the soil decreases, the combined protoplasm release occurs with decreasing cell swelling, the cell size and cell division rate tend to decrease dramatically, resulting in a decrease in the growth and photosynthetic rate of the plant (Nelissen et al., 2018). Due to the similarity process, water deficit affects the dry weight of the plant, and as water shortages reduce cell growth and division, it also reduces the number of seeds and panicles of the plant (Quinones et al., 2017). Under drought stress conditions, the plant has an appropriate cellular inflammation, in which case the compressive potential for cell development and its distribution is provided. Therefore, these conditions increase metabolic activity and the growth rate and development rate of the root, so that the growth of the root increases the absorption of food ions, and by increasing the turgor, the energy available through photosynthesis also increases (Fang et al., 2017). The above items show that, under drought stress and inappropriate conditions of cellular inflammation, the distribution of food to the root is increased compared to the stem, and the plant will not be able to provide the carbohydrate needed to continue the growth.

Correlation analysis in drought stress conditions (first year of experiment) showed that more traits play a role in justifying yield. If in normal conditions (second year of experiment), the effect of traits on grain yield was not similar to that of the first year. In drought stress condition, harvest index had a positive correlation with grain yield. If this was not the case in normal conditions. This means that plants prefer to invest in seed yields under stress conditions to preserve the survival of their generation, and for this purpose, the harvest index was high under stress conditions (Polania et al., 2016). The results showed that the relationship between relative water content and grain yield was negative. It seems that by increasing the amount of relative water content, the apertures of the plant more open and cause the water loss in the plant, and therefore reduces the grain yield. This result was not observed in the second year, because in the second year of agriculture, the amount of water has not been limited. By increasing the amount of relative water content, the amount of carbon dioxide is added to the plant, resulting in increased photosynthetic production. In general, the relative water content was lower in low stress conditions (first year of cultivation) compared to normal conditions (second year of cultivation). A number of researchers in their research have shown that by applying drought stress, stomatal conductance is reduced, then relative water content and photosynthesis begin to decrease (Bota et al., 2016; Zandalinas et al., 2018). A sharp decrease in stomatal conductance with a slight variation in relative water content indicates that rooting signals from drought stress conditions are the cause of stomatal closure and decreased photosynthesis. This chemical signal is the same as abscisic acid (Haworth et al., 2018). Ouyang et al., 2017 in studying the effects of water stress on wheat cultivars, observed that stressed plants had significantly lower stomatal conductivity than that of irrigated plants, which reduced leaf transpiration in drought conditions. The closure of stomata under stress conditions, in addition to the production of abscisic acid in the root and its transfer to the leaves, also reduces the potential for inflammation in the leaf, and is likely to be effective through the production of abscisic acid produced in the leaf itself (Vishwakarma et al., 2017).

Based on the results of correlation analysis, grain yield had a positive and significant correlation with root dry weight trait. Because in drought conditions (the first year of experiment), the plant improves root system by increasing its dry weight and therefore can play a positive role in justifying grain yield. Preferably, the drought-tolerant plant would prefer to devote more of its photosynthetic production to the accumulation of dry matter in the root to preserve this material in the stem and areal part of plants, since it will retain its ability to absorb more water from the soil (Avila et al., 2017). Considering that one of the main methods that plants use against drought stress is increasing root dry weight, this trait can be a suitable criterion for selection of tolerant genotypes from susceptible genotypes (Belachew et al., 2018). High-yielding groups in stress conditions (the first year of experiment) correlated with root length, so that genotypes with lower root length obtained higher yields. In addition, root dry weight was found to be higher in this group than in other groups. It seems that under stress conditions, tolerant genotypes obtained a higher yield by increasing root dry weight and decreasing root length.

In addition, the results of correlation in the second year showed that root dry weight was not positively correlated with yield because there was no moisture content in the second year and did not require the plant to 
invest a lot on the root system. Several scientists have shown that there is a positive and significant relationship between root dry weight and grain yield of plants under water deficit conditions (Kanbar et al., 2009; Atta et al., 2013; Fang et al., 2017). Based on the results of correlation analysis, there was a significant correlation between biologic yield and grain yield in first and second crop years. This significant result indicates that the biologic yield trait is not affected by environmental conditions, thus, there is a positive and significant relationship with grain yield in both normal and stress conditions. The radiation use efficiency in the first and second crop years was different. Also, the results showed that the use of light in different wheat genotypes was different. It seems that the difference in photosynthetic efficiency of cultivars can be effective in differentiating the behavior of cultivars in different weather conditions which is consistent with the results of a number of researchers (Adeboye et al., 2016; Greaves et al., 2017). Sinclair and Muchow, 1999 reported that the effect of light consumption is more influenced by plant genetics. For this reason, it was observed that there is a good variation in the efficiency of light consumption among different genotypes.

Based on the results of biplot in the first crop year, high yield genotypes included 'G14' $\left(263.00 \mathrm{~g} / \mathrm{m}^{2}\right)$, 'G20' $\left(264.50 \mathrm{~g} / \mathrm{m}^{2}\right)$, 'G18' $\left(214.00 \mathrm{~g} / \mathrm{m}^{2}\right)$ and ' $\mathrm{G} 19$ ' $\left(222.50 \mathrm{~g} / \mathrm{m}^{2}\right)$ has a higher correlation with $\mathrm{x} 4, \mathrm{x} 13, \mathrm{x} 12$, $\mathrm{x} 5, \mathrm{x} 1, \mathrm{x} 7, \mathrm{x} 8, \mathrm{x} 2$ and $\mathrm{x} 10$ traits. This result shows that one of the ways to achieve high yield in drought stress conditions is to improve the traits mentioned. In the second year of cultivation, high-yield genotypes included 'G7' $\left(356.42 \mathrm{~g} / \mathrm{m}^{2}\right)$ and 'G9' $\left(356.75 \mathrm{~g} / \mathrm{m}^{2}\right)$ have high correlation with X11 trait. These results indicate that under stress conditions, more traits play a role in justifying the grain yield of wheat. In addition, the important role of radiation use efficiency trait in yield in superior genotypes has been proved. These results showed the differences in use of radiation by genotypes and grain yield. The mean of radiation use efficiency traits in the first (2.64) and second (2.61) year showed that wheat genotypes had higher radiation use efficiency in stress conditions. In fact, the amount of light absorbed and the dry matter produced by plants is reduced in drought stress conditions (Flexas and Medrano, 2002). Under drought stress conditions, reduced in water availability decreased cell growth and subsequently reduces leaf area index, proportion of dry matter and consumption of light (Medrano et al., 2015). Biplot results show that radiation use efficiency was not the only effective factor in grain yield in superior genotypes. In other words, it can be concluded that under stress conditions, to cause stress tolerance and yield, grain yield is dependent on factors other than radiation use efficiency.

\section{Conclusions}

As it turned out from the results, there is a good variation between different wheat genotypes. In addition, wheat genotypes responded to different weather conditions (first and second crop year), so that grain yield and other measured traits were influenced by the environment. In general, it can be stated that in the first year of cultivation, genotypes 'G14' (263.00 g/m²), 'G20' $\left(264.50 \mathrm{~g} / \mathrm{m}^{2}\right)$, 'G18' $\left(214.00 \mathrm{~g} / \mathrm{m}^{2}\right)$ and 'G19' $\left(222.50 \mathrm{~g} / \mathrm{m}^{2}\right)$ had a higher yield and are suitable for cultivation in an environment that is exposed to drought stress. Also, according to different analyzes (principal component analysis and correlation analysis), the results showed that the traits $\mathrm{x} 4, \mathrm{x} 13, \mathrm{x} 12, \mathrm{x} 5, \mathrm{x} 1, \mathrm{x} 7, \mathrm{x} 8, \mathrm{x} 2$ and $\mathrm{x} 10$ had a stronger association with these genotypes. On the other hand, genotypes ' $G 7$ ' $\left(356.42 \mathrm{~g} / \mathrm{m}^{2}\right)$ and ' $G 9$ ' $\left(356.75 \mathrm{~g} / \mathrm{m}^{2}\right)$ had higher yields in the second crop year and are suitable for cultivation in normal conditions. Also, the results of principal component analysis and correlation analysis showed that the trait $\mathrm{x} 11$ have a stronger relationship with these genotypes. Finally, recognizable traits can be used to improve grain yield of wheat genotypes in future breeding program.

\section{Authors' Contributions}

Designed, performed and wrote the main manuscript text: AJ; Research farm operator: YS; Data analyzer: ASM; Draft the manuscript: FH. 
All authors read and approved the final manuscript.

\section{Acknowledgements}

This research received no specific grant from any funding agency in the public, commercial, or not-forprofit sectors.

\section{Conflict of Interests}

The authors declare that there are no conflicts of interest related to this article.

\section{References}

Abdel-Motagally FMF, El-Zohri M (2018). Improvement of wheat yield grown under drought stress by boron foliar application at different growth stages. Journal of the Saudi Society of Agricultural Sciences 17(2):178-185. https://doi.org/10.1016/j.jssas.2016.03.005.

Adeboye, OB, Schultz B, Adekalu KO, Prasad K (2016). Impact of water stress on radiation interception and radiation use efficiency of soybeans (Glycine max L. Merr.) in Nigeria. Brazilian Journal of Science and Technology 3(1):1524. https://doi.org/10.1186/s40552-016-0028-1.

Atta BM, Mahmood T, Trethowan TM (2013). Relationship between root morphology and grain yield of wheat in northwestern NSW, Australia. Australian Journal of Crop Science 7(13):2108-2113.

Avila R, Magalhaes PC, de Alvarenga AA, Lavinsky ADO, Campos CN, de Souza TC, Gomes Junior CC (2017). Drought-tolerant maize genotypes invest in root system and maintain high harvest index during water stress Revista Brasileira de Milho e Sorgo 15(3):450-460. https://doi.org/10.18512/rbms.v15i3.842.

Bange MP, Hawwer GL, Rickert KG (1997). Effect of leaf nitrogen on radiation use efficiency and growth of sunflower. Crop Science 37:1201-1207. https://doi.org/10.2135/cropsci1997.0011183X003700040029x.

Belachew KY, Nagel KA, Fiorani F, Stoddard FL (2018). Diversity in root growth responses to moisture deficit in young faba bean (Vicia faba L.) plants. PeerJ 6:e4401. https://doi.org/10.7717/peerj. 4401.

Bota J, Tomás M, Flexas J, Medrano H, Escalona JM (2016). Differences among grapevine cultivars in their stomatal behavior and water use efficiency under progressive water stress. Agricultural Water Management 16:91-99. https://doi.org/10.1016/j.agwat.2015.07.016.

Fang Y, Du Y, Wang J, Wu A, Qiao S, Xu B, Chen Y (2017). Moderate drought stress affected root growth and grain yield in old, modern and newly released cultivars of winter wheat. Frontiers in Plant Science 8:672-680. https://doiorg/10.3389/fpls.2017.00672.

Farnia A, Tork A (2015). Changes in yield and yield components of wheat cultivars underwater stress condition. International Journal of Life Science 9(5):103-107. https://doi.org/10.3126/ijls.v9i5.12707.

Fischer RA (2011). Wheat physiology: a review of recent developments. Crop Pasture Science 62(2):95-114. https://doi.org/10.1071/CP10344.

Flexas J, Medrano H (2002). Energy dissipation in C3 plants under drought. Functional Plant Biology 29(10):1209-1215. https://doi.org/10.1071/FP02015.

Gardner F, Pearce R, Mitchell RL (1985). Physiology of crop plants. Iowa State University Press. Ames. USA.

Gonzalez-Navarro OE, Griffiths S, Molero G, Reynolds MP, Slafer GA (2015). Dynamics of floret development determining differences in spike fertility in anelite population of wheat. Field Crops Research 172:21-31. https://doi.org/10.1016/j.fcr.2014.12.001.

Greaves GE, Yu-Min WANG (2017). The effect of water stress on radiation interception, radiation use efficiency and water use efficiency of maize in a tropical climate. Turkish Journal of Field Crops 22(1):114-125.

https://doi.org/10.17557/tifc.311904. 
Kanbar A, Toorchi M, Shashidhar H (2009). Relationship between root and yield morphological characters in rainfed low land rice (Oryza sativa L.). Cereal Research Communications 37(2):261-268. https://doi.org/10.1556/CRC.37.2009.2.14.

Learnmore M, Shimelis H, Dube E, Laing MD, Tsilo T (2016). Breeding wheat for drought tolerance: Progress and technologies. Journal of Integrative Agriculture 15(5):935-943. https://doi.org/10.1016/S2095-3119(15)61102-9.

Lonbani M, Arzani A (2011). Morpho-physiological traits associated with terminal drought stress tolerance in triticale and wheat. Agronomy Research 9(1-2):315-329.

Medrano H, Tomás M, Martorell S, Flexas J, Hernández E, Rosselló J, Bota J (2015). From leaf to whole-plant water use efficiency (WUE) in complex canopies: limitations of leaf WUE as a selection target. The Crop Journal 3(3):220228. https://doi.org/10.1016/j.cj.2015.04.002.

Nelissen H, Sun XH, Rymen B, Jikumaru Y, Kojima M, Takebayashi Y, De Block J (2018). The reduction in maize leaf growth under mild drought affects the transition between cell division and cell expansion and cannot be restored by elevated gibberellic acid levels. Plant biotechnology Journal 16(2):615-627. https://doi.org/10.1111/pbi.12801.

Ojeda J, Caviglia O, Agnusdei M, Errecart P (2018). Forage yield, water-and solar radiation-productivities of perennial pastures and annual crops sequences in the south-eastern Pampas of Argentina. Field Crops Research 221:19-31. https://doi.org/10.1016/j.fcr.2018.02.010.

Ouyang W, Struik PC, Yin X, Yang J (2017). Stomatal conductance, mesophyll conductance, and transpiration efficiency in relation to leaf anatomy in rice and wheat genotypes under drought. Journal of Experimental Botany 68(18):5191-5205. https://doi.org/10.1093/jxb/erx314.

Polania JA, Poschenrieder C, Beebe S, Rao IM (2016). Effective use of water and increased dry matter partitioned to grain contribute to yield of common bean improved for drought resistance. Frontiers in Plant Science 7:660-667. https://doi.org/10.3389/fpls.2016.00660.

Quinones C, Mattes N, Faronilo J, Jagadish KS (2017). Drought stress reduces grain yield by altering floral meristem development and sink size under dry-seeded rice cultivation. Crop Science 57(4):2098-2108.

Rana RM, Rehman SU, Ahmed J, Bilal M (2013). A comprehensive overview of recent advances in drought stress tolerance research in wheat (Triticum aestivum L.). Asian Journal Agriculture Biological 1(1):29-37.

Reynolds MP, Mujeeb-Kazi A, Sawkins M (2005). Prospects for utilizing plant-adaptive mechanisms to improve wheat and other crops in drought- and salinity-prone environments. Annul Application Biology 146:239-259. https://doi.org/10.1111/j.1744-7348.2005.040058.x.

Saeidi M, Abdoli M (2015). Effect of drought stress during grain filling on yield and its components, gas exchange variables, and some physiological traits of wheat cultivars. Agriculture Science Technology 17(4):885-895.

Sanchez-Garcia M, Royo C, Aparicio N, Martin-Sanchez JA, Alvaro F (2013). Genetic improvement of bread wheat yield and associated traits in Spain during the 20th century. Journal of Agricultural Science 151:105-118. https://doi.org/10.1017/S0021859612000330.

Sinclair TR, Muchow RC (1999). Radiation use efficiency. Advances in Agronomy 65:215-265. https://doi.org/10.1016/S0065-2113(08)60914-1.

Slafer GA, Araus JL (1998). Improving wheat responses to abiotic stresses. In: Slinkard AE (Ed). Proceedings of the ninth international wheat genetics symposium, Saskatoon, Saskatchewan, Canada, 2-7 August 1998. University Extension Press, Extension Division, University of Saskatchewan, Saskatoon, pp 201-213.

Vafa P, Naseri R, Mordi M (2014). The effect of drought stress on grain yield, yield components and protein content of durum wheat cultivars in Ilam Province, Iran. International Journal of Biological, Biomolecular, Agricultural, Food and Biotechnological Engineering 8(6):631-636.

Vishwakarma K, Upadhyay N, Kumar N, Yadav G, Singh J, Mishra RK, Sharma S (2017). Abscisic acid signaling and abiotic stress tolerance in plants: a review on current knowledge and future prospects. Frontiers in Plant Science 8:161-168. https://doi.org/10.3389/fpls.2017.00161.

Wang JY, Xiong YC, Li FM, Siddique KH, Turner NC (2017). Effects of drought stress on morpho-physiological traits, biochemical characteristics, yield, and yield components in different ploidy wheat: A meta-analysis. Advances in Agronomy 143:139-173. https://doi.org/10.1016/bs.agron.2017.01.002.

Wu W, Li C, Ma B, Shah F, Liu Y, Liao Y (2013). Genetic progress in wheat yield and associated traits in China since 1945 and future prospects. Euphytica 196(2):155-168. https://doi.org/10.1007/s10681-013-1033-9. 
Zandalinas SI, Mittler R, Balfagón D, Arbona V, Gómez-Cadenas A (2018). Plant adaptations to the combination of drought and high temperatures. Physiologia Plantarum 162(1):2-12. https://doi.org/10.1111/ppl.12540.

Zhang Zh, Christensen M, Nan Zh, Whish J, Bell L, Wang J, ... Sim R (2019). Plant development and solar radiation interception of four annual forage plants in response to sowing date in a semi-arid environment. Industrial Crops and Products 131:41-53. https://doi.org/10.1016/j.indcrop.2019.01.028.

OPEN ACCESS

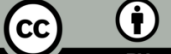

The journal offers free, immediate, and unrestricted access to peer-reviewed research and scholarly work. Users are allowed to read, download, copy, distribute, print, search, or link to the full texts of the articles, or use them for any other lawful purpose, without asking prior permission from the publisher or the author.

License - Articles published in Notulae Scientia Biologicae are Open-Access, distributed under the terms and conditions of the Creative Commons Attribution (CC BY 4.0) License.

(c) Articles by the authors; SHST, Cluj-Napoca, Romania. The journal allows the author(s) to hold the copyright/to retain publishing rights without restriction. 